\title{
Efficacy of disinfecting inanimate surfaces against coronavirus: a systematic review
}

\author{
Eficácia de desinfectar superfícies inanimadas contra coronavirus: uma revisão sistemática \\ Eficacia de la desinfección de superfícies inanimadas contra coronavirus: una revisión sistemática
}

Received: 08/05/2021 | Reviewed: 08/10/2021 | Accept: 08/12/2021 | Published: 08/15/2021

Isabela Bittencourt Basso

ORCID: https://orcid.org/0000-001-9511-047X

Pontifícia Universidade Católica do Paraná, Brazil

E-mail: isabelabbasso@ hotmail.com

Rosane Sampaio Santos

ORCID: https://orcid.org/0000-0001-6400-5706

Tuiuti University of Paraná, Brazil

E-mail: rosane.santos2@utp.br

Angela Graciela Deliga Schroder

ORCID: https://orcid.org/0000-0002-1852-8423

Center for advanced studies in Systematic Review and Meta-analysis, Brazil

E-mail: dra.angela@digitalface.com.br

Glória Cortz Ravazzi

ORCID: https://orcid.org/0000-0002-6574-9878

Tuiuti University of Paraná, Brazil

E-mail: gcortz87@hotmail.com

Flavio Magno Gonçalves

ORCID: https://orcid.org/0000-0002-7972-2844

Tuiuti University of Paraná, Brazil

E-mail: flaviomagno93@yahoo.com.br

José Stechman-Neto

ORCID: https://orcid.org/0000-0002-0259-2420

Tuiuti University of Paraná, Brazil

E-mail: stechman1@gmail.com

Bianca Simone Zeigelboim

ORCID: https://orcid.org/0000-0003-4871-2683

Tuiuti University of Paraná, Brazil

E-mail: bianca.zeigelboim@utp.br

Bruna Povh

ORCID: https://orcid.org/0000-0003-0624-1465 Center for advanced studies in Systematic Review and Meta-analysis, Brazil

E-mail: bruna_povh3@hotmail.com

Cristiano Miranda de Araujo

ORCID: https://orcid.org/0000-0003-1325-4248

Tuiuti University of Paraná, Brazil

E-mail: cristiano.araujo@utp.br

Odilon Guariza-Filho

ORCID: https://orcid.org/0000-0001-9799-1223

Pontifícia Universidade Católica do Paraná, Brazil

E-mail: odilongfilho@gmail.com

\begin{abstract}
Human coronaviruses tend to persist on dry surfaces for 2 to 9 days, necessitating infection control and prevention protocols using biocidal agents. This systematic review aimed to answer the following focused question: What is the effectiveness of disinfectants on inanimate surfaces against the coronavirus? The acronym "PICOS" was used to represent the eligibility of studies: $\mathrm{P}=$ population (inanimate surfaces contaminated with coronavirus); $\mathrm{I}=$ intervention (disinfectants); $\mathrm{C}=$ comparison (studies with any type of control or studies that used a control group); $\mathrm{O}$ $=$ outcomes (coronavirus inactivation on different types of inanimate surfaces); and $\mathrm{S}=$ study design (in vitro studies). The seven databases used were PubMed/Medline, EMBASE, Latin American and Caribbean Literature on Health Sciences (LILACS), Web of Science, Scopus, LIVIVO, and Cochrane Library. The gray literature was also used as an information source through Google Scholar, ProQuest, and Open Gray. The search resulted in 6639 references, and 21 articles were used in the qualitative analysis. The results showed that all studied biocidal solutions provided some degree of decontamination and inactivation of the coronavirus, depending on the concentration of the disinfectant solution, the time of exposure of the product to the pathogen and the type of surface.
\end{abstract}

Keywords: SARS-CoV-2; Disinfectants; Inanimate surface; Biocidal agent; Coronavirus. 


\begin{abstract}
Resumo
Os coronavírus humanos tendem a persistir em superfícies secas por 2 a 9 dias, necessitando de controle de infecção e protocolos de prevenção usando agentes biocidas. Esta revisão sistemática teve como objetivo responder à seguinte questão focada: Qual a eficácia dos desinfetantes em superfícies inanimadas contra o coronavírus? A sigla "PICOS" foi utilizada para representar a elegibilidade dos estudos: $\mathrm{P}=$ população (superfícies inanimadas contaminadas com coronavírus); I = intervenção (desinfetantes); $\mathrm{C}$ = comparação (estudos com qualquer tipo de controle ou estudos que utilizaram grupo controle); $\mathrm{O}=$ desfechos (inativação do coronavírus em diferentes tipos de superfícies inanimadas); e $\mathrm{S}=$ desenho do estudo (estudos in vitro). As sete bases de dados utilizadas foram PubMed / Medline, EMBASE, Literatura Latino-Americana e do Caribe em Ciências da Saúde (LILACS), Web of Science, Scopus, LIVIVO e Biblioteca Cochrane. A literatura cinzenta também foi usada como fonte de informação por meio do Google Scholar, ProQuest e Open Gray. A busca resultou em 6.639 referências, e 21 artigos foram utilizados na análise qualitativa. Os resultados mostraram que todas as soluções biocidas estudadas proporcionaram algum grau de descontaminação e inativação do coronavírus, dependendo da concentração da solução desinfetante, do tempo de exposição do produto ao patógeno e do tipo de superfície.
\end{abstract}

Palavras-chave: SARS-CoV-2; Desinfetantes; Superfície inanimada; Agente biocida; Coronavírus.

\title{
Resumen
}

Los coronavirus humanos tienden a persistir en superficies secas durante 2 a 9 días, lo que requiere protocolos de prevención y control de infecciones con agentes biocidas. Esta revisión sistemática tuvo como objetivo responder la siguiente pregunta focalizada: ¿Cuál es la efectividad de los desinfectantes en superficies inanimadas contra el coronavirus? Se utilizó el acrónimo "PICOS" para representar la elegibilidad de los estudios: P = población (superficies inanimadas contaminadas con coronavirus); I = intervención (desinfectantes); C = comparación (estudios con cualquier tipo de control o estudios que utilizaron un grupo de control); $\mathrm{O}=$ resultados (inactivación del coronavirus en diferentes tipos de superficies inanimadas); y $\mathrm{S}=$ diseño del estudio (estudios in vitro). Las siete bases de datos utilizadas fueron PubMed / Medline, EMBASE, Literatura de Ciencias de la Salud de América Latina y el Caribe (LILACS), Web of Science, Scopus, LIVIVO y Cochrane Library. La literatura gris también se utilizó como fuente de información a través de Google Scholar, ProQuest y Open Gray. La búsqueda resultó en 6.639 referencias y se utilizaron 21 artículos en el análisis cualitativo. Los resultados mostraron que todas las soluciones biocidas estudiadas proporcionaron algún grado de descontaminación e inactivación del coronavirus, dependiendo de la concentración de la solución desinfectante, el tiempo de exposición del producto al patógeno y el tipo de superficie.

Palabras clave: SARS-CoV-2; Desinfectantes; Superficie inanimada; Agente biocida; Coronavirus.

\section{Introduction}

SARS-CoV-2 is a virus transmitted from person to person through direct or indirect contact via droplets dispersed by coughing, sneezing, or speaking, actions through which the infected individual deposits the active virus on inanimate surfaces and that can serve as transmission vector. (Akram, 2020; Cirrincione et al., 2020; Peng et al., 2020).

Human coronaviruses are known to persist on dry surfaces for 2 to 9 days, depending on the ambient temperature and relative humidity (Akram, 2020). In environments with a high flow of people that are likely to be contaminated, such as hospitals and primary health units, the virus remains in circulation for a longer time, as it spreads more frequently (De Andrade, 2020). Thus, it is necessary to control and prevent infection via protocols using biocidal agents capable of inactivating these pathogens in an attempt to control their spread and ensure the safety of health agents and people circulating in these environments (De Andrade, 2020; Yen et al., 2020).

The World Health Organization (WHO) suggests that cleaning of contaminated inanimate surfaces and environments is an essential strategy for disease control (Organization, 2014). A variety of chemicals are available for this purpose, most commonly based on povidone-iodine (PVP-I), sodium hypochlorite, alcohols, phenolic compounds, and hydrogen peroxide (G. Kampf, Todt, Pfaender, \& Steinmann, 2020; Organization, 2014).

It is also known that UV radiation is an efficient physical disinfectant used to inactivate microorganisms, including the coronavirus. One factor that can influence the effect of UV radiation on the virus is the relative humidity of the air because water acts as a protective mechanism on the viral surface. In drier environments, the virus does not absorb water, facilitating the radiation-induced breakdown of its genetic material and compromising its replication (Hamzavi et al., 2020; Tseng \& Li, 2007). 
A recent systematic review was published to summarize antiseptics capable of disinfecting surfaces contaminated by COVID-19 (Molina \& Abad-Corpa, 2020). However, only studies published between the years 2016 to 2020 were selected using a simplified search strategy and without following the criteria for conducting a systematic review. For that reason, it is necessary to conduct a more comprehensive search, due to the need to understand how the coronavirus works in the face of exposure to disinfectants in environments where there is a great potential for transmission of this virus, since it will be very useful in the current pandemic moment. Therefore, the objective of this systematic review was to answer the following focused question: What is the effectiveness of disinfectants against the coronavirus on inanimate surfaces?

\section{Methodology}

\subsection{Protocol and registration}

This review was registered on the PROSPERO website (International Prospective Register of Systematic Review Center for Reviews and Dissemination University of York) - CRD42020186897 and was performed according to the Preferred Reporting Items for Systematic Reviews and Meta-Analysis Checklist (PRISMA).

\subsection{Eligibility criteria}

\subsubsection{Inclusion criteria}

In vitro experimental studies were included in which at least one type of surface was evaluated for the presence/absence of the coronavirus after the use of physical or chemical disinfectants. There was no restriction on the study language or time of publication.

\subsubsection{Exclusion criteria}

The following exclusion criteria were applied: a) studies that evaluated the survival time of the virus on surfaces without the use of disinfectant, b) studies that did not evaluate the coronavirus, c) studies that evaluated the coronavirus in water/aerosol/sewage, d) studies that evaluated any other animate surfaces, e) studies that did not evaluate the outcome of interest or that contained incomplete data, and f) descriptive studies such as reviews, letters, conference abstracts, expert opinions, and case reports.

\subsection{Information sources and search strategy}

Combinations of words and appropriate truncations were adapted for each of theelectronic databases selected: Cochrane Library, EMBASE, Latin American and Caribbean Literature in Health Sciences (LILACS), LIVIVO, PubMed/Medline, Scopus, and Web of Science. Additionally, the gray literature was used as a source of information through Open Grey, Google Scholar and ProQuest. Searches of the electronic databases and gray literature were carried out on June 2, 2020, and all references were managed. All duplicate studies were removed using the appropriate software (EndNote ${ }^{\circledR}$ X7 Thomson Reuters, Philadelphia, PA). A manual search for references was performed in all included studies and in the most current guidelines in the literature that address the use of disinfectant agents against coronavirus on inanimate surfaces. An expert on the subject was consulted via e-mail to verify any possible publication on the subject and indication of any relevant article that could be included. The full search strategy is publicly available on the OSF (Open Science Framework) platform as Appendix 1 (https://osf.io/qw7yf/?view_only=91d7b96d7bdb4c369d7b3f3afc77bf8c).

\subsection{Study selection}

The selection of articles was conducted in two phases. In the first phase, two pairs of reviewers (I.B.B. and J.S.N.; 
A.G.D.S and O.G.F.) independently reviewed the titles and abstracts of all references. All articles that did not meet the previously established eligibility criteria were excluded at this stage. In the second phase, the reviewers, again in pairs (I.B.B. and J.S.N.; A.G.D.S. and O.G.F.), read the full text of the articles selected in the first phase, also independently. Whenever disagreement arise and a lack of consensus persisted after discussion, a third reviewer (C.M.A.) was involved in the final decision.

To facilitate independent reading in both phases, the Rayyan website (http://rayyan.qcri.org) was used, such that the reviewers were shielded in all evaluations, and a fifth member of the team (C.M.A.) acted as moderator.

\subsection{Data collection process}

Two reviewers independently (I.B.B. and O.G.F.) collected the information from the included studies, and this information was discussed with two other members of the team (J.S.N and A.G.D.S.). The gathered data consisted of study characteristics (author, year of publication, country), type of surface (metal, glass, plastic, wood, fabric, surgical mask), coronavirus family virus, temperature and relative humidity, type of disinfectant used, time of exposure, factors of influence and conclusion. If data were missing or incomplete in the article, attempts were made to contact the authors to obtain the relevant unpublished information.

\subsection{Risk of bias in individual studies}

The methodology of the selected observational studies was assessed using the bias risk tool known as the MetaAnalysis of Statistics Assessment and Review Instrument (MASTARI). The risk of bias was categorized as "high" if the study had a "yes" scores of less than 49\%, "moderate" if the study had "yes" scores between 50\% to 69\%, and "low" if the study had more than $70 \%$ "yes" scores for bias risk questions.

Two reviewers (I.B.B. and O.G.F.) independently assessed the included studies and classified the quality of the report, performance bias, selection bias, and detection bias. The risk of these different domains was categorized as "low risk", "unclear risk", or "high risk" of bias.

\section{Results}

\subsection{Study selection}

The search strategy retrieved a total of 6639 references from the seven electronic databases. After removing duplicate references and reading the titles and abstracts (phase 1), forty-six articles were selected for complete reading. Thirty-one articles were excluded because they did not meet the stipulated eligibility criteria, leaving 15 articles (Figure 1). Removed articles have been listed and are publicly available on the OSF platform as Appendix 2. Six additional articles were included from the gray literature, consultation with the expert, and a list of references, resulting in a final number of 21 articles for qualitative synthesis (Figure 1). The Kappa coefficient, which has the purpose of measuring the degree of agreement between the reviewers, was $>0.8$, indicating excellent agreement. The references retrieved at each step can be seen in Figure 1 . 
Figure 1 - Flowchart of literature search and selection criteria.

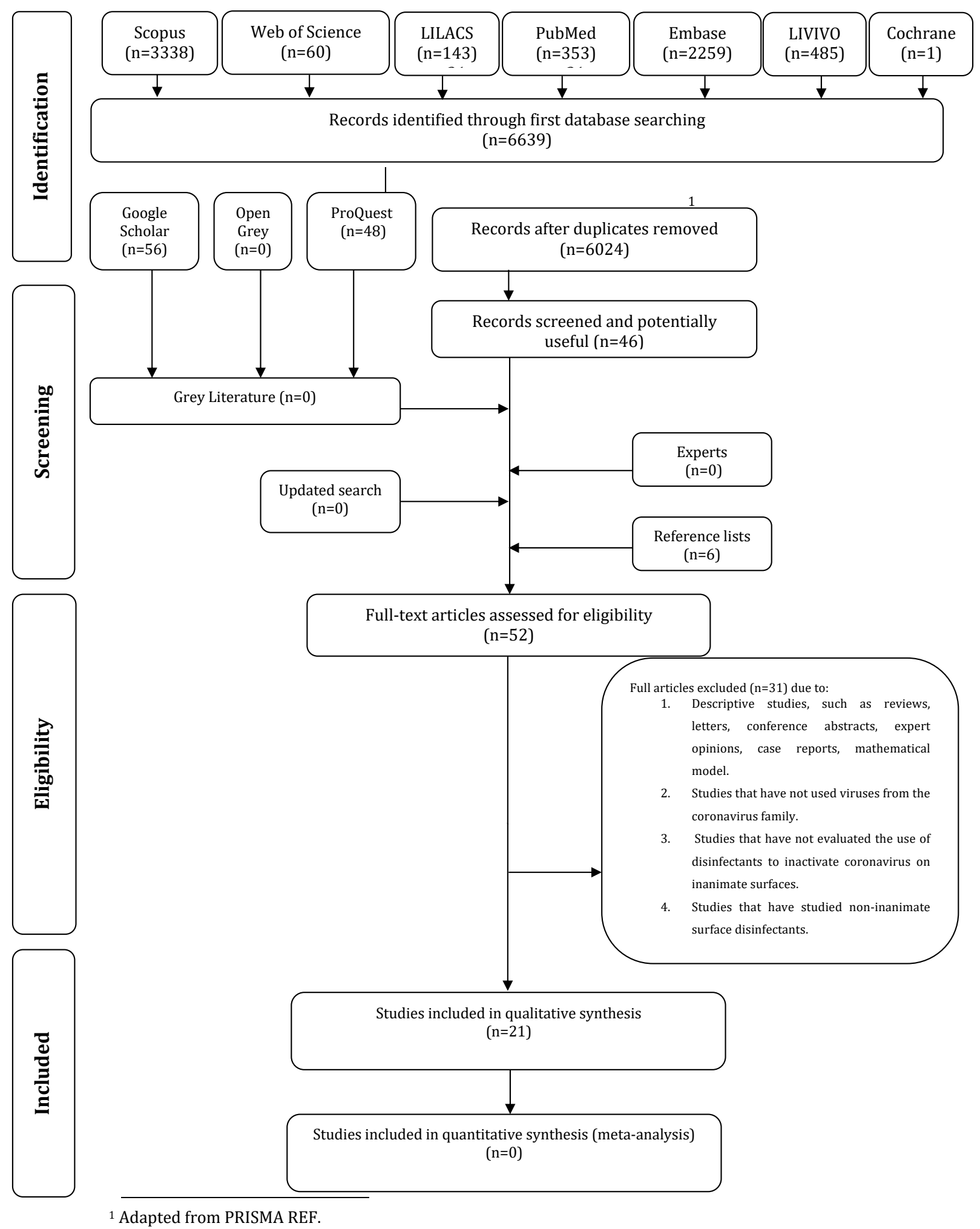

Source: Research Data (2021).

\subsection{Study characteristics}

All articles included are in vitro laboratory studies published between 1989 and 2020 and conducted in Belgium, China, Canada, Germany, Italy, Japan, The United States of America, and the United Kingdom. The pathogens studied in these 
articles were SARS-CoV-1, MERS-CoV, SARS-CoV-2, Human coronavirus 229-E (HCV-229E) and surrogates for coronaviruses (TGEV, bacteriophage MS2, Phi6). The studies evaluated the following disinfectants: UV radiation, strong Mikrobac (benzalkonium chloride and laurylamine), Korsolin FF (benzalkonium chloride, glutaraldehyde and didecyldimonium chloride), Dismozon pur (magnesium monoperphthalate), Korsolex basic (glutaraldehyde and ethylenedioxy), sodium hypochlorite (hypochlorine), chloramine $\mathrm{T}$ (organoochlorine), sodium hypochlorite and potassium bromide (mixed halide), povidone-iodine (iodophore), ethanol (alcohol), glutaraldehyde, n-alkyl (50\% C14, 40\% C12, 10\% C16), dimethyl benzyl ammonium chloride (quaternary ammonium), household bleach (1:49 and 1:99), chloroxylenol (0.05\%), chlorhexidine $(0.05 \%)$, benzalkonium chloride $(0.1 \%)$, Steris Vesphene IIse non-sterile disinfectant cleaner $(9.09 \%$ Ophenylphenol, 7.66\% P-tertiary amylphenol), Cidex OPA (0.55\% ortho-phthalaldehyde), 2-propanol, 2-propanol and 1propanol, didecyldimethyl ammonium, chloride, hydrogen peroxide and formaldehyde, hydrogen peroxide vapor, and ozone. The characteristics of the studies were listed in table 1, which is publicly available on the OSF platform as Table 1.

\subsection{Risk of bias within studies}

Of the total articles included, twenty studies were classified as having a low risk of bias. Only one study was classified as having a moderate risk of bias, mainly due to the lack of information sufficient to provide an adequate judgment (Figure 2 and Supplementary material 1).

Figure 2 - Meta-Analysis of Statistics Assessment and Review Instrument (MASTARI) critical appraisal tools. Green indicates a low risk of bias, yellow indicates an unclear risk of bias, and red indicates a high risk of bias.

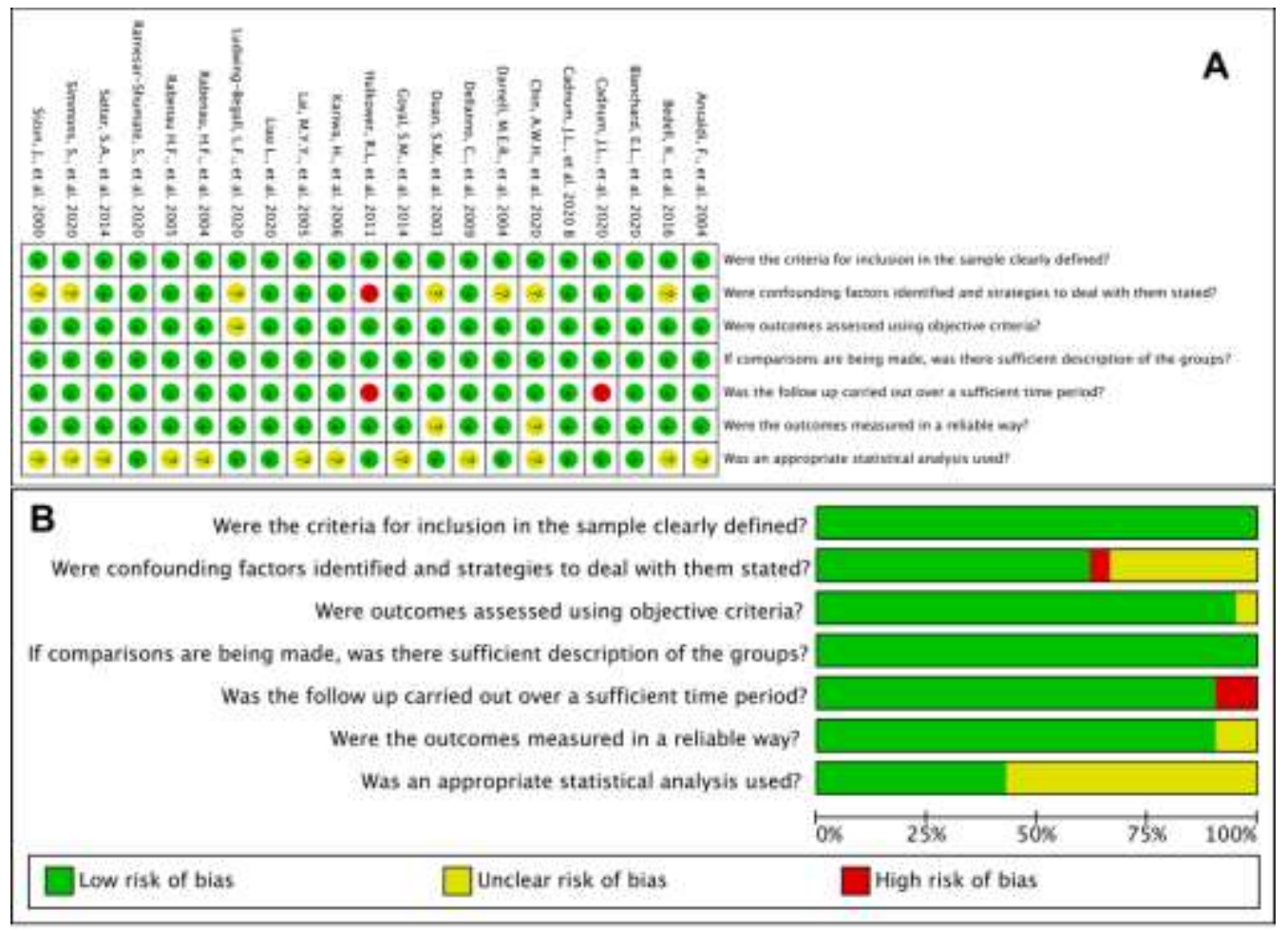

Source: Research Data (2021). 
Supplementary material 1 - Risk of bias for the studies included in the qualitative analysis, assessed by "Meta-Analysis of Statistics Assessment and Review Instrument” (MASTARI) critical appraisal tools. Risk of bias was categorized as High when the study reaches up to $49 \%$ score "yes", Moderate when the study reached $50 \%$ to $69 \%$ score "yes", and Low when the study reached more than $70 \%$ score "yes".

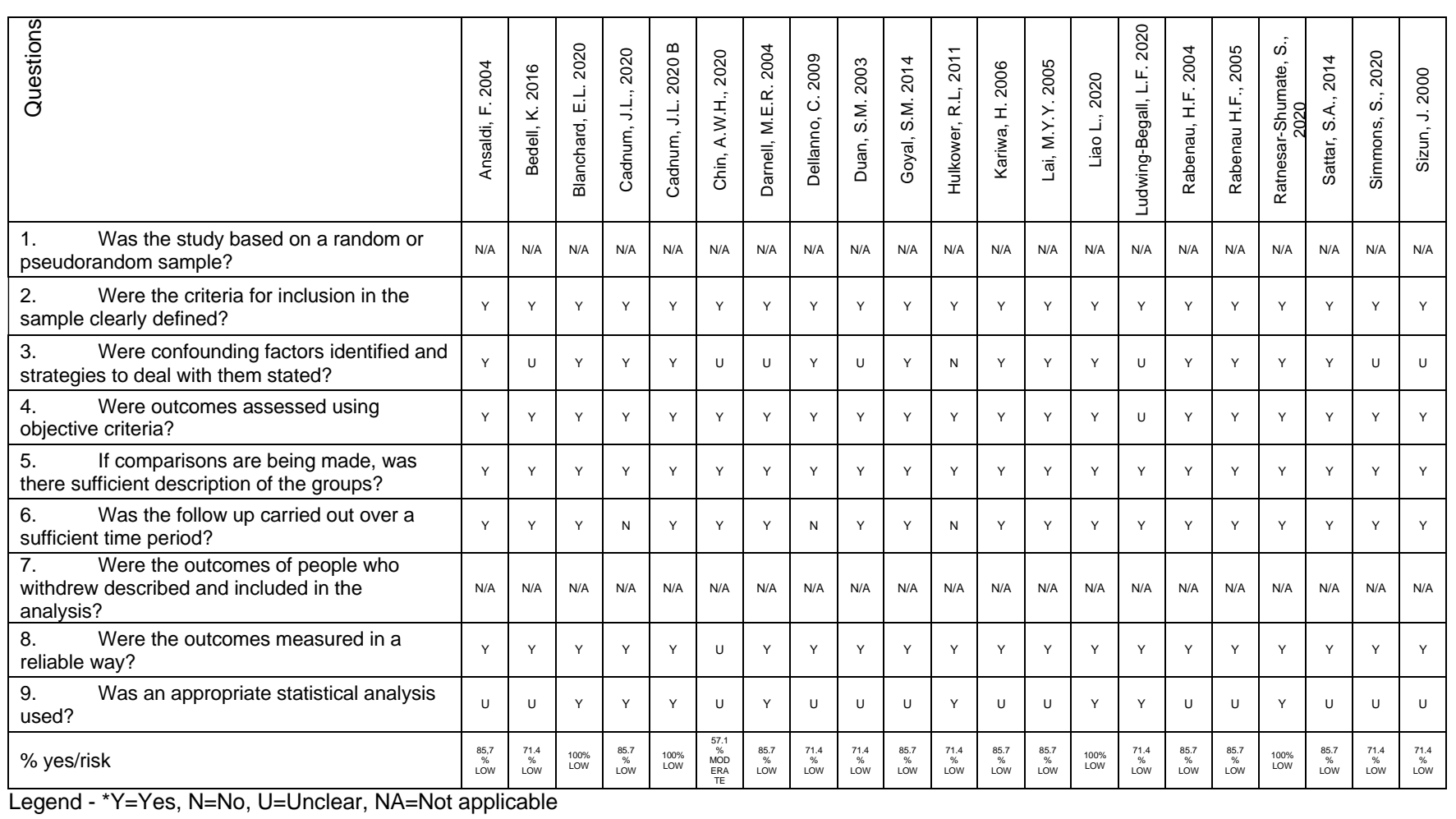

Source: Research Data (2021).

\subsection{Results of individual studies}

UV radiation has been shown to be useful in rapid decontamination of hard and smooth surfaces (Cadnum, Li, et al., 2020). The application of 2 to 5 minutes of UV radiation on a surface contaminated by the SARS-CoV-1 and MERS-CoV virus resulted in undetectable levels of the virus, with a reduction in infectivity. (Ansaldi et al., 2004; Bedell, Buchaklian, \& Perlman, 2016). On the other hand, Duan et al., 2003, observed that when UV radiation was applied to culture medium, the viral infectivity was reduced to a very low level and to an undetectable level only after 30 and 60 minutes of irradiation, respectively (Duan et al., 2003). When UV radiation was applied in a band similar to that of sunlight (250-280 nm) in a suspension similar to saliva deposited on $19 \mathrm{~mm}$ dry stainless steel coupons, it took 6.8 minutes to inactivate $90 \%$ of the SARSCoV-2 virus and 14.3 minutes in culture medium (Ratnesar-Shumate et al., 2020). UV radiation also demonstrated effectiveness in reducing the viral infectivity of SARS-CoV-2 on hard environmental surfaces, with a reduction of 4.12 Log 10 $(99.99 \%)$ in 2 minutes of exposure and was able to promote a reduction of $>4.79 \log 10(99.99 \%)$ on N95 respirators after 5 minutes of exposure (Simmons et al., 2020). Darnel et al. (2004) observed that UVA and UVC radiation demonstrated differences in the time of inactivation of the SARS-CoV-1 virus, with faster inactivation of the virus (1 to 6 minutes) with UVC radiation than with UVA, which did not demonstrate significant inactivation for up to 15 minutes (Darnell, Subbarao, Feinstone, \& Taylor, 2004).

After 5 minutes of incubation of the SARS-CoV-1 and SARS-CoV-2 virus, the virus appears to be inactivated in several disinfectants (Chin et al., 2020; Lai, Cheng, \& Lim, 2005). Chin et al., 2020, assessed the stability of the SARS-CoV-2 virus exposed on surfaces such as paper, tissue paper, wood, glass, banknote, cloth, stainless steel, plastic, mask (inner and 
outer layer), under various disinfectants (household bleach (1: 49/1: 99), ethanol 70\%, povidone-iodine, chloroxylenol, chlorhexidine, benzalkonium chloride), except for hand soap, no virus was detected after 5 minutes (Chin et al., 2020). According to the study by Sizun et al., 2020, coronavirus was more sensitive to a povidone-iodine solution, requiring less of this solution to neutralize the virus (Sizun, Yu, \& Talbot, 2000). This solution might deliver results close to those of $70 \%$ ethanol in level of reduction of the virus on a surface (sluminum, sterile latex surgical glove, sterile sponges) (Kariwa, Fujii, \& Takashima, 2006). Hulkower et al., 2011, observed that ethanol solutions (concentrations of 62-71\%) were the most efficient disinfectants among six different types of hospital disinfectants, requiring 1 minute of exposure to the virus for a decrease of $>3 \log 10$ for two viruses similar to SARS-CoV-1. Hypochlorite (1:100 dilution) was the least effective disinfectant, producing an infectivity reduction factor of $<1 \log 10$ in the same period (Hulkower, Casanova, Rutala, Weber, \& Sobsey, 2011). However, Cadnum et al., 2020, reported that application of diluted sodium hypochlorite disinfectant using an electrostatic spray can provide quick and effective decontamination of portable equipment and large open areas (Cadnum, Jencson, et al., 2020). Ansaldi et al. (2004), observed that the SARS-CoV-1 virus appears to be entirely inactivated by domestic disinfectants such as peracetic acid, $70 \%$ ethanol, $0.05 \%$ and $0.1 \%$ sodium hypochlorite, $1 \%$ chlorhexidine digluconate and 2-benzylchlorophenol at $2 \%$, after exposure of $<1$ minute, of which only $0.1 \%$ sodium hypochlorite and 2 -benzyl-chlorophenol at $2 \%$ were quickly effective in destroying viral RNA at an undetectable level after <2 minutes of contact (Ansaldi et al., 2004). The biocidal agents Mikrobac forte (benzalkonium chloride and laurylamine), Korsolin FF (benzalkonium chloride, glutaraldehyde and didecyldimony chloride), and Dismozon pur (magnesium monoperphthalate) also demonstrated efficiency in inactivating the SARS-CoV-1 virus, at $0.5 \%$ over within 30 minutes period, on inanimate surfaces and medical instruments (Rabenau, Kampf, Cinatl, \& Doerr, 2005). Dellano et al. (2009), observed that household disinfectants containing triclosan, parachloromethaxylenol, pine oil, or some quaternary compound with $79 \%$ ethanol in their composition demonstrated viral decrease within 30 seconds when used on a coronavirus-like a virus if used according to the instructions (Dellanno, Vega, \& Boesenberg, 2009).

Coronavirus showed stability over a wide $\mathrm{pH}$ range at room temperature $\left(22^{\circ} \mathrm{C}\right.$; $\left.\mathrm{pH} 3-10\right)(\mathrm{Chin}$ et al., 2020$)$ and is more sensitive to extreme $\mathrm{pH}$ levels (Darnell et al., 2004). The temperature of the biocidal agent also seems to influence the deactivation of the virus. Darnell et al. (2004), observed that formalin and glutaraldehyde were unable to completely inactivate the SARS-CoV-1 virus at a temperature of $4^{\circ} \mathrm{C}$, even after exposure for three days. However, formalin was able to partially inactivate the virus at higher temperatures $\left(25^{\circ} \mathrm{C}\right.$ and $\left.37^{\circ} \mathrm{C}\right)$ occurred partially or completely in 1 day, and gluteraldehyde completely inactivated the virus under that same temperature over a period of 2 days (Darnell et al., 2004).

Hydrogen peroxide was tested on stainless steel disks and can be considered for the disinfection of surfaces contaminated by a coronavirus (Goyal, Chander, Yezli, \& Otter, 2014). The use of 20 ppm ozone for 40 minutes at a relative humidity $>70 \%$ and room temperature $\left(21-24^{\circ} \mathrm{C}\right)$ promoted a $99.99 \%$ reduction in viral infectivity in a variety of PPE (Blanchard et al., 2020). In addition, higher levels of humidity associated with higher concentrations of ozone promoted faster virus inactivation (Blanchard et al., 2020; Ludwig-Begall et al., 2020). However, Liao et al. (2020) reported that heat $\left(\leq 85^{\circ} \mathrm{C}\right)$ under various humidity conditions was the most promising and nondestructive method for preserving the filtering properties of N95 respirators (Liao et al., 2020).

\section{Discussion}

Although the actual potential of transmitting the coronavirus found on inanimate surfaces via touch is not known, it is known that the virus can remain active for an extended period, depending on the type of surface, the relative humidity, and the ambient temperature (Günter Kampf, 2020; G. Kampf et al., 2020; Rabenau et al., 2005). The qualitative synthesis of the studies found in this systematic review demonstrates that exposure of the virus to some types of disinfectants for a specific 
time is effective in reducing the infectivity of diseases caused by the coronavirus.

In environments where health treatments are performed, such as dental clinics, it is necessary to use disinfectants on surfaces for which there is a greater risk of exposure to the virus, such as PPE and countertops made of contaminated materials, to eliminate the chance of contamination of COVID-19 by healthcare professionals or patients. This disinfection eliminates pathogens according to their sensitivity to a chemical agent (Hota, 2004). Coronavirus shows greater stability on different

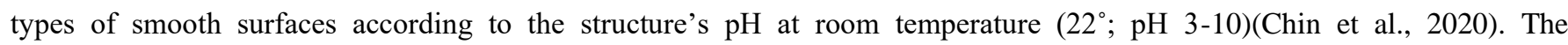
temperature of the environment is also a factor that must be considered in the effectiveness of the biocidal agent because at lower temperatures, the virus tends to remain active for a more extended period than at high temperatures (Darnell et al., 2004).

The products based on ethanol in concentrations of 62 and $71 \%$ proved to be the most efficient according to certain authors and were able to decrease the viral load to $>3 \log 10$ on average in only 1 minute of exposure, thus reducing the infectivity of the SARS-CoV to below the detectable level (Hulkower et al., 2011; Kariwa et al., 2006). PVP-I solutions proved to be as useful as $70 \%$ ethanol in reducing the virus on inanimate surfaces such as aluminum, sterile latex surgical gloves, sterile sponges and medical instruments, in addition to using less of this chemical for effectiveness (Kariwa et al., 2006; Sizun et al., 2000). According to Kariwa et al. (2006), the exposure of SARS-CoV to several products based on PVP-I for 1 minute was not sufficient to eliminate the exposed virus, but when this solution was applied for 2 minutes, the virus became undetectable on the surface of medical instruments. (Kariwa et al., 2006). Sodium hypochlorite (1:100 dilution) was the least effective disinfectant, producing an infectivity reduction factor of $<1 \log 10$ in the same period compared with other biocidal agents. (Hulkower et al., 2011). Nevertheless, some studies report that this solution is capable of decontaminating large areas quickly and effectively, proving to be one of the most effective disinfectants against SARS-CoV and viruses that can be studied as a substitute for coronavirus when compared with other solutions (Ansaldi et al., 2004; Cadnum, Jencson, et al., 2020; Goyal et al., 2014).

Only one author shows ozone as a disinfectant agent of choice in the health field, which it can also promote a $99.99 \%$ reduction in viral infectivity when used at $20 \mathrm{ppm}$, ambient temperature $\left(21-24^{\circ} \mathrm{C}\right)$ and relative humidity $>70 \%$, but it takes an average of 40 minutes for ozone to be effective in eliminating the virus (Blanchard et al., 2020).

Ultraviolet germicidal irradiation (UVGI), in addition to promoting efficient disinfection of infectious pathogens, has the benefit of not causing damage to surface, which is a positive point for use on personal protective equipment in the health area. In this review, application of 2 to 5 minutes of UV radiation decreased the infectivity of the virus. Ansaldi et al., 2004, (Ansaldi et al., 2004) observed that exposing the SARS-CoV-1 virus to UV radiation for 2 minutes reduced its infectivity to undetectable levels. In contrast, Duan S.M. et al. (2003)(Duan et al., 2003), also observed that by exposing a culture medium to UV radiation, viral infectivity was reduced to an undetectable level in up to 60 minutes. The difference between these results noted in this review can be explained by the type of UV radiation used and the application distance between the radiation source and the surface. According to Darnel et al. (2004), the type of UV radiation used can demonstrate different results with respect to viral inactivation. Additionally, a distance of $3 \mathrm{~cm}$ associated with UVC radiation seems to demonstrate efficacy (Darnell et al., 2004).

The studies available in the literature on the topic of this systematic review have heterogeneous methodologies, making it impossible to carry out a quantitative analysis of the subject. The impossibility of including other study designs, in addition to in vitro laboratory studies, is also a limitation that must be considered. Despite these limitations, knowledge of the available evidence on the topic is of utmost importance for clinical practice, especially in a pandemic situation due to SARS$\mathrm{CoV}-2$, and can aid in decisions on biosafety in environments, thus decreasing the risk of indirect contamination and fighting the proliferation of the disease. 


\section{Conclusion}

All biocidal solutions studied in this systematic review showed some degree of decontamination and inactivation of the coronavirus, depending on the product's concentration, the time of exposure of the pathogen to the disinfectant and the type of contaminated inanimate surface. Nevertheless, 70\% ethanol and PVP-I appear to be more efficacy than the other options, as they require less product and a shorter time of exposure of the virus to such solutions. The heat has been shown to inactivate the coronavirus in large amounts without damage filtration properties of PPE, such as N95 respirators.

\section{References}

Akram, M. Z. (2020). Inanimate surfaces as potential source of 2019-nCoV spread and their disinfection with biocidal agents. VirusDisease. 10.1007/s13337020-00603-0

Ansaldi, F., Banfi, F., Morelli, P., Valle, L., Durando, P., Sticchi, L., \& Crovari, P. (2004). SARS-CoV, influenza A and syncitial respiratory virus resistance against common disinfectants and ultraviolet irradiation. Journal of Preventive Medicine and Hygiene, 45(1-2), 5-8.

Bedell, K., Buchaklian, A. H., \& Perlman, S. (2016). Efficacy of an Automated Multiple Emitter Whole-Room Ultraviolet-C Disinfection System Against Coronaviruses MHV and MERS-CoV. Infect Control Hosp Epidemiol, 37(5), 598-599. 10.1017/ice.2015.348

Blanchard, E. L., Lawrence, J. D., Noble, J. A., Xu, M., Joo, T., Ng, N. L., \& Finn, M. G. (2020). Enveloped Virus Inactivation on Personal Protective Equipment by Exposure to Ozone. medRxiv. 10.1101/2020.05.23.20111435

Cadnum, J. L., Jencson, A. L., Livingston, S. H., Li, D. F., Redmond, S. N., Pearlmutter, B., \& Donskey, C. J. (2020). Evaluation of an electrostatic spray disinfectant technology for rapid decontamination of portable equipment and large open areas in the era of SARS-CoV-2. Am J Infect Control, 48(8), 951-954. 10.1016/j.ajic. 2020.06 .002

Cadnum, J. L., Li, D. F., Jones, L. D., Redmond, S. N., Pearlmutter, B., Wilson, B. M., \& Donskey, C. J. (2020). Evaluation of Ultraviolet-C Light for Rapid Decontamination of Airport Security Bins in the Era of SARS-CoV-2. Pathog Immun, 5(1), 133-142. 10.20411/pai.v5i1.373

Chin, A. W. H., Chu, J. T. S., Perera, M. R. A., Hui, K. P. Y., Yen, H.-L., Chan, M. C. W., \& Poon, L. L. M. (2020). Stability of SARS-CoV-2 in different environmental conditions. The Lancet Microbe, 1(1), e10. 10.1016/s2666-5247(20)30003-3

Cirrincione, L., Plescia, F., Ledda, C., Rapisarda, V., Martorana, D., Moldovan, R. E., \& Cannizzaro, E. (2020). COVID-19 Pandemic: Prevention and Protection Measures to Be Adopted at the Workplace. Sustainability, 12(9). 10.3390/su12093603

Darnell, M. E., Subbarao, K., Feinstone, S. M., \& Taylor, D. R. (2004). Inactivation of the coronavirus that induces severe acute respiratory syndrome, SARSCoV. J Virol Methods, 121(1), 85-91. 10.1016/j.jviromet.2004.06.006

De Andrade, F. P. D. B. P., C. (2020). Use of chlorine solutions as disinfectant agents in health units to contain the spread of COVID-19. Journal of Health \& Biological Sciences, 8, 1-9. 10.12662/2317-3206jhbs.v8i1.3256.p1-9.2020

Dellanno, C., Vega, Q., \& Boesenberg, D. (2009). The antiviral action of common household disinfectants and antiseptics against murine hepatitis virus, a potential surrogate for SARS coronavirus. Am J Infect Control, 37(8), 649-652. 10.1016/j.ajic.2009.03.012

Duan, S. M., Zhao, X. S., Wen, R. F., Huang, J. J., Pi, G. H., Zhang, S. X., \& Team, S. R. (2003). Stability of SARS coronavirus in human specimens and environment and its sensitivity to heating and UV irradiation. Biomed Environ Sci, 16(3), 246-255.

Goyal, S. M., Chander, Y., Yezli, S., \& Otter, J. A. (2014). Evaluating the virucidal efficacy of hydrogen peroxide vapour. J Hosp Infect, 86(4), 255-259. 10.1016/j.jhin.2014.02.003

Hamzavi, I. H., Lyons, A. B., Kohli, I., Narla, S., Parks-Miller, A., Gelfand, J. M., \& Ozog, D. M. (2020). Ultraviolet germicidal irradiation: Possible method for respirator disinfection to facilitate reuse during the COVID-19 pandemic. J Am Acad Dermatol, 82(6), 1511-1512. 10.1016/j.jaad.2020.03.085

Hota, B. (2004). Contamination, disinfection, and cross-colonization: are hospital surfaces reservoirs for nosocomial infection? Clin Infect Dis, 39(8), 11821189. $10.1086 / 424667$

Hulkower, R. L., Casanova, L. M., Rutala, W. A., Weber, D. J., \& Sobsey, M. D. (2011). Inactivation of surrogate coronaviruses on hard surfaces by health care germicides. Am J Infect Control, 39(5), 401-407. 10.1016/j.ajic.2010.08.011

Kampf, G. (2020). Potential role of inanimate surfaces for the spread of coronaviruses and their inactivation with disinfectant agents. Infection Prevention in Practice, 2(2). 10.1016/j.infpip.2020.100044

Kampf, G., Todt, D., Pfaender, S., \& Steinmann, E. (2020). Persistence of coronaviruses on inanimate surfaces and their inactivation with biocidal agents. $J$ Hosp Infect, 104(3), 246-251. 10.1016/j.jhin.2020.01.022

Kariwa, H., Fujii, N., \& Takashima, I. (2006). Inactivation of SARS coronavirus by means of povidone-iodine, physical conditions and chemical reagents. Dermatology, 212 Suppl 1, 119-123. 10.1159/000089211

Lai, M. Y., Cheng, P. K., \& Lim, W. W. (2005). Survival of severe acute respiratory syndrome coronavirus. Clin Infect Dis, 41(7), e67-71. 10.1086/433186 Liao, L., Xiao, W., Zhao, M., Yu, X., Wang, H., Wang, Q., \& Cui, Y. (2020). Can N95 Respirators Be Reused after Disinfection? How Many Times? ACS nano. 10.1021/acsnano.0c03597 
Research, Society and Development, v. 10, n. 10, e452101019100, 2021

(CC BY 4.0) | ISSN 2525-3409 | DOI: http://dx.doi.org/10.33448/rsd-v10i10.19100

Ludwig-Begall, L. F., Wielick, C., Dams, L., Nauwynck, H., Demeuldre, P.-F., Napp, A., \& Thiry, E. (2020). Decontamination of face masks and filtering facepiece respirators via ultraviolet germicidal irradiation, hydrogen peroxide vaporisation, and use of dry heat inactivates an infectious SARS-CoV-2 surrogate virus. medRxiv preprint. 10.1101/2020.06.02.20119834

Molina, J. L., \& Abad-Corpa, E. (2020). Desinfectantes Y AntisÉpticos Frente Al Coronavirus: SÍntesis De Evidencias Y Recomendaciones. Enfermería Clínica. 10.1016/j.enfcli.2020.05.013

Organization, W. H. (2014). Infection prevention and control of epidemic - and pandemic -prone acute respiratory infections in health care. WHO Guidelines, 45 .

Peng, X., Xu, X., Li, Y., Cheng, L., Zhou, X., \& Ren, B. (2020). Transmission routes of 2019-nCoV and controls in dental practice. Int J Oral Sci, 12(1), 9. 10.1038/s41368-020-0075-9

Rabenau, H. F., Kampf, G., Cinatl, J., \& Doerr, H. W. (2005). Efficacy of various disinfectants against SARS coronavirus. J Hosp Infect, 61(2), 107-111. 10.1016/j.jhin.2004.12.023

Ratnesar-Shumate, S., Williams, G., Green, B., Krause, M., Holland, B., Wood, S., \& Dabisch, P. (2020). Simulated Sunlight Rapidly Inactivates SARS-CoV2 on Surfaces. J Infect Dis, 222(2), 214-222. 10.1093/infdis/jiaa274

Simmons, S., Carrion, R., Alfson, K., Staples, H., Jinadatha, C., Jarvis, W., \& Stibich, M. (2020). Disinfection effect of pulsed xenon ultraviolet irradiation on SARS-CoV-2 and implications for environmental risk of COVID-19 transmission. medRxiv, 2020.2005.2006.20093658. 10.1101/2020.05.06.20093658

Sizun, J., Yu, M. W., \& Talbot, P. J. (2000). Survival of human coronaviruses 229E and OC43 in suspension and after drying onsurfaces: a possible source ofhospital-acquired infections. J Hosp Infect, 46(1), 55-60. 10.1053/jhin.2000.0795

Tseng, C. C., \& Li, C. S. (2007). Inactivation of viruses on surfaces by ultraviolet germicidal irradiation. J Occup Environ Hyg, 4(6), 400-405. $10.1080 / 15459620701329012$

Yen, M. Y., Schwartz, J., King, C. C., Lee, C. M., Hsueh, P. R., Society of Taiwan Long-term Care Infection, P., \& Control. (2020). Recommendations for protecting against and mitigating the COVID-19 pandemic in long-term care facilities. J Microbiol Immunol Infect, 53(3), 447-453. 10.1016/j.jmii.2020.04.003 